\title{
Study on anodic oxidation parameters for removal of pesticide imidacloprid on a modified tantalum surface by lead dioxide film
}

\author{
Brahim M.B.*, Soukrata S., Ammar H.B., Samet Y. \\ Electrochemistry and Environmental Laboratory, Department of Materials Engineering, National Engineering School of Sfax, University \\ of Sfax, B.P. 1173, 3038, Sfax, Tunisia
}

Received: 25/03/2019, Accepted: 09/01/2020, Available online: 16/01/2020

*to whom all correspondence should be addressed: e-mail: benbrahim.mabrouk@yahoo.com

https://doi.org/10.30955/gnj.003119

\begin{abstract}
The commercial imidacloprid (IMD) insecticide [1-(6chloro-3-pyridinyl) methyl-4,5-dihydro-N-nitro- $1 \mathrm{H}$ imidazole-2-amine] is widely used for the enhancement of crop production, but the intensive use of this insecticide has caused serious environmental problems. This work presents an electrochemical process for the removal of this insecticide using galvanostatic electrolysis at modified tantalum surface by lead dioxide film anode $\left(\mathrm{Ta}\left(\mathrm{PbO}_{2}\right)\right)$ anode. The electrolytic process was monitored by chemical oxygen demand (COD). The influence of operating parameters, such as current density, initial concentration of IMD, temperature and initial $\mathrm{pH}$ value was investigated. The COD decay follows a pseudo first-order kinetic and the process was under mass transport control. COD removal reach $97 \%$ when using an apparent current density of 100 $\mathrm{mA} \mathrm{cm}{ }^{-2}$, initial COD of $953 \mathrm{mg} \mathrm{L}^{-1}$ and at $25^{\circ} \mathrm{C}$ after $4.5 \mathrm{~h}$ electrolysis time.
\end{abstract}

Keywords: Imidacloprid, electrochemical degradation, anodic oxidation, $\mathrm{Ta}\left(\mathrm{PbO}_{2}\right)$ anode, hydroxyl radicals.

\section{Introduction}

Crop yield is often minimized by the presence of undesirable plants, insects and various diseases. For each of these "enemies", the industry has created a defense commonly known pesticide. However, the intensive use of these pesticides in agriculture leads to adverse impacts in the aquatic and terrestrial ecosystems. In addition, several studies have found that, many pesticides are more toxic and environmentally persistent, creating serious acute health problems and environmental impacts (Ecobichon, 2012). Many studies showed that pesticides were detected in agricultural products (Wen et al., 2013; Paranthaman et al., 2012) and in groundwater (Johnson et al., 2001; Kadian et al., 2008).

Imidacloprid [1-(6-chloro-3-pyridylmethyl)-Nnitroimidazolidin-2-ylidenamine] a relatively stable chloronicotinic insecticide, classified as Category I due to its high leaching potential (USEPA, 2009). It could easily contaminate water sources, leading to negative environmental and health effects. Indeed, acute exposure to Imidacloprid may cause apathy, spasms and thyroid lesions. This insecticide is used to control a number of agricultural insect such as aphids, whiteflies, leafhoppers, termites (Mullins, 1993; Tomizawa and Casida, 2005). IMD residues may occur in water and agricultural products therefore they pose a potential hazard for consumers. For these reasons, it is necessary to develop technologies for the removal of this compound.

Advanced Oxidation Process (AOP) is a chemical treatment method that has been growing in the wastewater management industry. It is a highly suggested method for the removal of problematic organic matter. The basic principle of AOP involves the production of hydroxyl radicals $\left(\mathrm{HO}^{\circ}\right)$, which can be generated from hydrogen peroxide $\left(\mathrm{H}_{2} \mathrm{O}_{2}\right)$, ozone, photo-catalysis, or oxidants in combination with using ultraviolet (UV) radiation. In some cases, two or more radical generators are used in combination. However, it is the $\mathrm{HO}^{*}$ that is mainly responsible for the degradation of organic compounds. This radical then goes through a succession of chemical reactions to form several products and by-products (Bokare and Choi, 2014). Theoretically, AOPs should fully mineralize organic compounds to carbon dioxide and water as illustrated in equation 1.

$$
\mathrm{RH}+\mathrm{HO}^{\circ} \mathrm{R}+\mathrm{H}_{2} \mathrm{O}
$$

Anodic oxidation or electro-oxidation is one of the most popular advanced oxidation procedures for elimination of dissolved organic pollutants and consists in the oxidation of organic matter in an electrolytic cell. In anodic oxidation, organic pollutants are directly destroyed by reaction with hydroxyl radical $\left(\mathrm{HO}^{\circ}\right)$ formed at the anode surface from water oxidation (Torres et al., 2003).

When using $\mathrm{Ta}\left(\mathrm{PbO}_{2}\right)$ anode, properties of this material enable the oxidation of organic compounds mediated by hydroxyl radicals. The mechanism consists in the $\mathrm{H}_{2} \mathrm{O}$ oxidation at the anode surface to produce a slightly adsorbed hydroxyl radical on the electrode that reacts with the organic molecules $(R)$ that reach the vicinity of the anode producing $\mathrm{CO}_{2}$ and $\mathrm{H}_{2} \mathrm{O}$ as shown in the following equations: 


$$
\begin{aligned}
& \mathrm{Ta}\left(\mathrm{PbO}_{2}\right)[]+\mathrm{H}_{2} \mathrm{O} \rightarrow \mathrm{Ta}\left(\mathrm{PbO}_{2}\right)[\mathrm{HO}]+\mathrm{H}^{+}+\mathrm{e}^{-} \\
& \mathrm{Ta}\left(\mathrm{PbO}_{2}\right)[\mathrm{HO}]+\mathrm{Ta}\left(\mathrm{PbO}_{2}\right)[\mathrm{R}] \\
& \rightarrow \mathrm{Ta}\left(\mathrm{PbO}_{2}\right)[]+\mathrm{Ta}\left(\mathrm{PbO}_{2}\right)[\mathrm{RO}]+\mathrm{H}^{+}+\mathrm{e}^{-} \\
& \mathrm{Ta}\left(\mathrm{PbO}_{2}\right)[\mathrm{HO} \cdot]+\mathrm{Ta}\left(\mathrm{PbO}_{2}\right)[\mathrm{RO}] \\
& \rightarrow 2 \mathrm{Ta}\left(\mathrm{PbO}_{2}\right)[]+\mathrm{xCO}_{2}+\mathrm{yH}^{+}+\mathrm{ze}^{-}
\end{aligned}
$$

Thus, to oxidize such effluent, anode material should have besides high overvoltage for oxygen evolution, high electrical conductivity, chemical inertness and low cost. Among the possible electrode materials which meet these criteria, the so-called dimensionally stable anodes (DSA) (e.g., $\mathrm{PbO}_{2}$ and $\mathrm{SnO}_{2}$ ) have received considerable attention in recent years. These anodes have been successfully employed to destroy a variety of pollutants, phenols (Xiaoyue et al., 2013), dyes (José et al., 2013), pesticides (Olfa et al., 2013) and so on.

The goal of the present work was attempted to use electrocatalytic oxidation using $\mathrm{Ta}\left(\mathrm{PbO}_{2}\right)$ anode for the treatment of IMD in aqueous solutions. The electrocatalytic oxidation of IMD was followed by chemical oxygen demand, UV-Vis spectrophotometric and square wave voltammetry method.

\section{Experimental}

\subsection{Reagents}

Solutions contain quantities of IMD taken from an emulsifiable concentrate (Confidor $200 \mathrm{SL}$ from Bayer CropScience) containing $200 \mathrm{~g} \mathrm{~L}^{-1}$ IMD. All solutions were freshly prepared with ultrapure water (modelMillipore Direct- $\mathrm{Q}^{\mathrm{TM}}$ 3). Sodium hydroxide $(\mathrm{NaOH})(0.005 \mathrm{M})$ and sulfuric acid $\left(\mathrm{H}_{2} \mathrm{SO}_{4}\right)(0.01 \mathrm{M})$ of analytic grade were employed as conductive electrolytes and for $\mathrm{pH}$ adjustment.

\subsection{Preparation of the modified tantalum surface}

\subsubsection{Tantalum surface treatment}

Pre-treatments of the tantalum substrate (rectangular tantalum plates $5 \mathrm{~cm} \times 1 \mathrm{~cm} \times 1 \mathrm{~mm}$ ) were carried out before anodization to ensure good adhesive lead dioxide film. Tantalum was first roughened to increase the adhesion of $\mathrm{PbO}_{2}$ deposit via subjecting its surface to mechanical abrasion using silica grains with an average diameter of $0.3 \mathrm{~mm}$ projected under 5 bar pressure. It was then cleaned to remove sand particles or any other particles lodged in the metal surface. This was carried out by degreasing with acetone because of its ease of application and its great penetrating power, and then ultrasonically rinsed in ultrapure water during $10 \mathrm{~min}$. Uniform and well adhesive deposit necessitates a smooth surface with no oxides (formed spontaneously on contact with oxygen in the air) or scales. To ensure this, the tantalum substrate was soaked for $30 \mathrm{~s}$ in hydrofluoric acid (40\% weight) at room temperature and then abundantly rinsed with ultrapure water. This chemical treatment corresponds to dissolution of the surface layer formed of tantalum and tantalum oxide according to following reactions:

$$
\begin{aligned}
& \mathrm{Ta}+5 \mathrm{HF} \rightarrow \mathrm{TaF}_{5}+\frac{5}{2} \mathrm{H}_{2} \\
& \mathrm{Ta}_{2} \mathrm{O}_{5}+10 \mathrm{HF} \rightarrow 2 \mathrm{TaF}_{5}+5 \mathrm{H}_{2} \mathrm{O}
\end{aligned}
$$

\subsubsection{Electrochemical deposition of $\mathrm{PbO}_{2}$ film}

The lead dioxide was deposited galvanostatically on the pretreated tantalum substrate by electrochemical anodization of an aqueous $\mathrm{Pb}\left(\mathrm{NO}_{3}\right)_{2}$ solution $(1 \mathrm{M})$ placed in a two-compartment Pyrex glass cell $\left(\mathrm{V}=150 \mathrm{~cm}^{3}\right)$ thermoregulated at $65{ }^{\circ} \mathrm{C}$. The electrodeposition of $\mathrm{PbO}_{2}$ film was carried out at an apparent current density of 10 $\mathrm{mA} \mathrm{cm} \mathrm{cm}^{-2}$ for 0.5 hours, then at $20 \mathrm{~mA} \mathrm{~cm}^{-2}$ for the same period and finally at $50 \mathrm{~mA} \mathrm{~cm} \mathrm{~cm}^{-2}$ for one hour. The average masse of $\mathrm{PbO}_{2}$ was $0.21 \mathrm{~g} \mathrm{~cm}^{-2}$. The deposit obtained was a grey porous material with strong adherence.

\subsection{Electrode characterization}

The morphology of the electrode was examined using an optical microscope (SZ-45-PS; CALTEX Scientific Inc., Irvine, CA).

The X-ray diffraction (XRD) patterns were recorded on a D8 Advance X-diffractometer ( $\mathrm{Cu} \mathrm{K}, \lambda=0.154 \mathrm{~nm}$ ) (Bruker, Germany) operating at $40 \mathrm{kV}$ and $30 \mathrm{~mA}$. The diffraction patterns were collected at $25^{\circ} \mathrm{C}$ and over an angular range of 5 to $100^{\circ}$ with a step size of $0.05^{\circ}$ per step and a dwell time of $12 \mathrm{~s}$ per increment.

\subsection{Electrolysis}

Galvanostatic electrolysis of IMD aqueous solutions $\left(150 \mathrm{~cm}^{-3}\right)$ was carried out in a two-compartment thermostatic cell (Figure 1 ). The cathode is a cylindrical platinum grid $(\varphi=4 \mathrm{~cm}, \mathrm{l}=5 \mathrm{~cm})$. The anode is made up of $\mathrm{Ta}\left(\mathrm{PbO}_{2}\right)$ anode plate arranged symmetrically around the cathode. The geometric working surface of each plate was $5 \mathrm{~cm}^{2}$. IMD solutions were electrolyzed in galvanostatic mode using a DC power supply (model ABTP 530 Françoise d'Instrumentation, France). The range of applied current density was 50 to $100 \mathrm{~mA} \mathrm{~cm}$. The $\mathrm{pH}$ of solution was adjusted, before and over the course of the electrolysis, by adding either concentrated sulfuric acid or sodium hydroxide solutions.

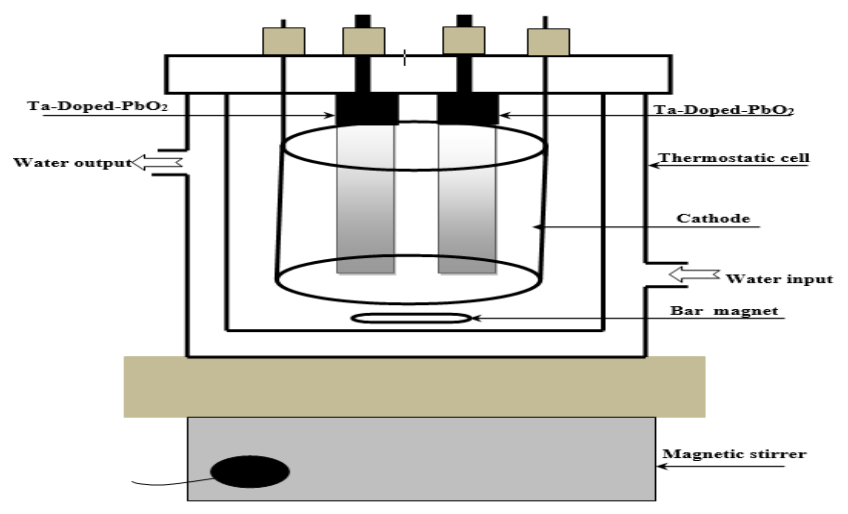

Figure 1. Electrolytic cell 


\subsection{Analysis}

\subsubsection{Chemical oxygen demand (COD)}

The COD measurement during the processing permitted the evaluation of the kinetic of organic matter decay and the instantaneous current efficiency (ICE). COD was determined by the dichromate method (Kolthof et al., 1969).

The absorbance measurements were carried out with a UV-visible spectrophotometer (Shimadzu 1650 PC).

\subsubsection{Square-wave voltammetry analysis}

The Square-wave voltammetry measurement was performed using a potentiostat-galvanostat (VoltaLab PST050), and a conventional three-electrode cell at $25^{\circ} \mathrm{C}$. BDD was used as working electrode for voltammetric experiments. A platinum wire was used as a counter electrode and a saturated calomel electrode (SCE) was used as reference electrode.

\subsubsection{UV-Vis spectrophotometer analysis}

The treated samples were analyzed using UV-Vis spectrophotometer (Shimadzu 1650 PC). The samples were filtered through Millipore filters $(0.45 \mu \mathrm{m})$ and absorbance of the compound was measured at corresponding $\lambda$ max at $270 \mathrm{~nm}$. From standard solutions, calibration curves were prepared and concentrations of experimental solutions were thus determined.

\section{Results and discussion}

\subsection{Crystalline structure of $\mathrm{Ta}\left(\mathrm{PbO}_{2}\right)$ electrode}

$\mathrm{Ta}\left(\mathrm{PbO}_{2}\right)$ electrode is one of the most widely investigated anode materials for electrochemical oxidation due to its chemical stability, high electronic conductivity, and low cost of material (Chen, 2004). The XRD patterns of $\mathrm{Ta}\left(\mathrm{PbO}_{2}\right)$ anode electrode are shown in Figure 2. The $\mathrm{X}$-ray diffraction data were recorded by using $\mathrm{Cu} \mathrm{K}_{\alpha}$ radiation (1.54 $\AA$ ). The intensity data were collected over a $2 \theta$ range of $5-100$. As can be seen, several remarkable peaks at $23.63^{\circ}, 29.09^{\circ}, 32.30^{\circ}, 38.09^{\circ}, 49.53^{\circ}, 63.63^{\circ}, 76.36^{\circ}$ and $80^{\circ}$ are attributed to the $\beta-\mathrm{PbO}_{2}$ substrate (Xiaoyue et al., 2013; José et al., 2013; Xu et al., 2015).

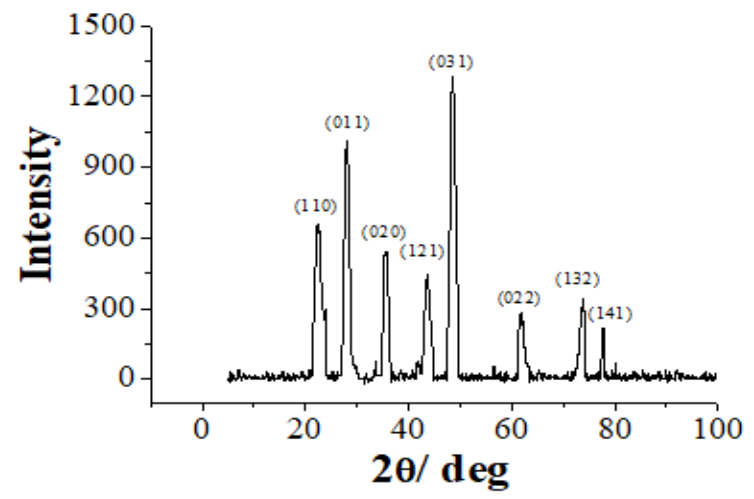

Figure 2. X-ray diffraction (XRD) pattern of $\beta-\mathrm{PbO}_{2}$ electrode prepared by electro-deposition

\subsection{Surface morphology}

The morphology of the prepared electrodes was investigated by optical microscope as shown in Figure 3. Before the polishing and chemical stripping in hydrofluoric acid $40 \%$, the tantalum substrate micrographs presented a rough and reproducible surface. However, after the electrochemical deposition film, the lead oxide was stable and adherent almost on all tantalum plate surfaces. Furthermore, the $\mathrm{Ta}\left(\mathrm{PbO}_{2}\right)$ anode deposit is very porous and presents a high roughness.

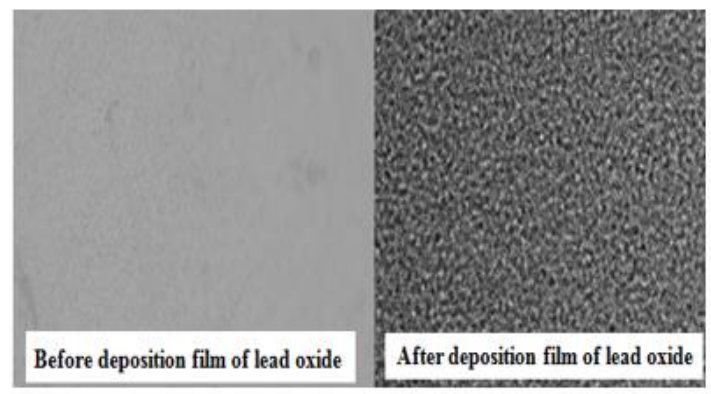

Figure 3. The morphology of the prepared of $\mathrm{Ta}\left(\mathrm{PbO}_{2}\right)$ anode by optical microscope in electrolysis of IMD aqueous solution before and after chemical deposition of lead oxide

\subsection{Stability of $\mathrm{Ta}\left(\mathrm{PbO}_{2}\right)$ electrode}

The dissolution of $\mathrm{PbO}_{2}$ was studied by following changes in the concentration of lead in solution during the electrolysis of a solution of IMD during all experimental electrolysis on the $\mathrm{Ta}\left(\mathrm{PbO}_{2}\right)$ anode. Figure 4 shows that, the lead oxide dissolves rapidly in the first hours of electrolyses, and then the concentration of lead in solution increases slightly with the electrical charge. Should be noted that. the standard in drinking water and surface water intended is $15 \mathrm{mg} \mathrm{L}^{-1}$ according to the new European directive (USEPA, 2009).

To test the repeatability of electro-oxidation efficiency of $\mathrm{Ta}\left(\mathrm{PbO}_{2}\right)$ anode, 4 anodic oxidation tests were continued using a $500 \mathrm{mg} \mathrm{L}^{-1}$ aqueous solution of IMD, corresponding

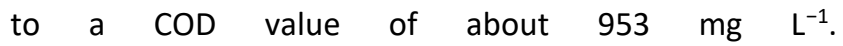
After each test, the $\mathrm{Ta}\left(\mathrm{PbO}_{2}\right)$ anode was only washed by distilled water and dried using a blower. After $4.5 \mathrm{~h}$ of each test of electrolysis the experimental results demonstrate a constant efficiency of COD removal in the range of 95-97\%.

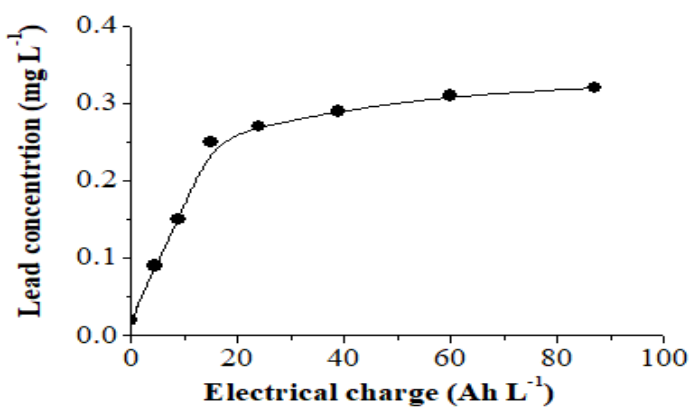

Figure 4. Evolution of lead concentration as a function of electrical charge measured during all tests done in this work 


\subsection{Influence of current density}

The role of current density has been followed, testing values smaller that the previously considered as the optimum. It corresponds to the ratio between the applied current and the surface of the working electrode. Therefore, the current density can be altered by changing the current and/or the surface of the working electrode.

To achieve complete mineralize of IMD to $\mathrm{CO}_{2}$ and $\mathrm{H}_{2} \mathrm{O}$, 66 mole of $\mathrm{HO}^{\bullet}$ is necessary to mineralize one mole of IMD (Eq. (7))

$$
\left.\mathrm{C}_{9} \mathrm{H}_{10} \mathrm{ClN}_{5} \mathrm{O}_{2}+66 \mathrm{HO} \rightarrow 9 \mathrm{CO}_{2}+35 \mathrm{H}_{2} \mathrm{O}+5 \mathrm{HNO}_{3}+\mathrm{HCl}\right)
$$

So, it is necessary to choose suitable current density for the generation of amount of hydroxyl radicals sufficient to accomplish mineralization of IMD to $\mathrm{CO}_{2}$ and $\mathrm{H}_{2} \mathrm{O}$.

The influence of the applied current density on the COD removal during the electrochemical oxidation of IMD at the $\mathrm{Ta}\left(\mathrm{PbO}_{2}\right)$ anode is shown in Figure 5. It could be seen from this figure that the removal of COD significantly enhanced with the increase of current density. For example, after 270 minutes of electrolysis the COD percent removal increased from $24 \%$ to $97 \%$ when the current density increased from 50 to $100 \mathrm{~mA} \mathrm{~cm}$. The process could be attributed to an increase of the amount of hydroxyl radicals with the increase of the applied current (Belhadj Ammar et al., 2016; Rkik et al., 2017; Ben Brahim et al., 2016). However, increasing of the current density beyond $100 \mathrm{~mA} \mathrm{~cm}^{-2}$ involves a reduction the yield of the degradation reaction. The oxidation rate decreased due to the rise of side reactions such as oxygen evolution (Eq. (8)) and/or electrolyte decomposition (Eq. (9)) which occur at the anode surface (Panizza and Cerisola, 2005; Sires et al., 2008).

$$
\begin{aligned}
& 2 \mathrm{H}_{2} \mathrm{O} \rightarrow \mathrm{O}_{2}+4 \mathrm{H}^{+}+4 \mathrm{e}^{-} \\
& 2 \mathrm{SO}_{4}^{2-} \rightarrow \mathrm{s}_{2} \mathrm{O}_{8}^{2-}+2 \mathrm{e}^{-}
\end{aligned}
$$

Therefore, the current density of $100 \mathrm{~mA} \mathrm{~cm}^{-2}$ was selected as the optimal parameter in the following experiments.

The instantaneous current efficiency (ICE) can be defined as the art of the current directly used for the oxidation of the organic compounds (inset of Figure 5). The increased current density resulted in a decrease in current efficiency. The ICE can also be defined by Eq. (10) (Comninellis and Pulgarin, 1991).

$$
I C E=\frac{\operatorname{COD}(t)-\operatorname{COD}(t+\Delta t)}{81 t} F V
$$

where, $\mathrm{F}$ is the Faraday constant $(96,487 \mathrm{C} / \mathrm{mol}), \mathrm{V}$ the volume of the solution $(\mathrm{L}), \operatorname{COD}(\mathrm{t})$ and $\operatorname{COD}(t+\Delta t)$ are the chemical oxygen demands at times $t$ and $t+\Delta t$ (in $\mathrm{g} \mathrm{O}_{2} \mathrm{~L}^{-1}$ ), respectively, and $I$ is the current $(A)$.

We notice that the instantaneous current efficiency is below $100 \%$ (inset of Figure 5) revealing that the degradation process of IMD was controlled more by electrode kinetics than by mass transfer in the tested current density range.

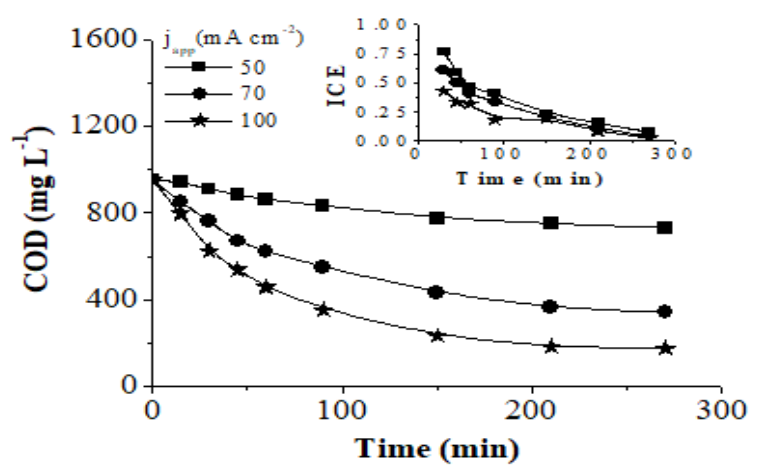

Figure 5. Influence of the apparent applied current density on the trends of $C O D$ and ICE during electrolysis of IMD $\left(\mathrm{COD}_{0}\right.$ $\left.953 \mathrm{mg} \mathrm{L}^{-1}\right)$ on the $\mathrm{Ta}\left(\mathrm{PbO}_{2}\right)$ anode. Electrolyte: $\mathrm{Na}_{2} \mathrm{SO}_{4} 2 \mathrm{~g} \mathrm{~L}^{-1}$; $\mathrm{pH}=3.0$ and $\mathrm{T}=25^{\circ} \mathrm{C}$

The decay of COD exhibits an exponential behavior with all applied current indicating a first-order reaction kinetics. If we suppose that the active surface of the electrode remains constant during electrolysis, we can consider that the hydroxyl radical's concentration is in a steady state and therefore, the oxidation rate expression can be written by Eq. (11):

$$
\mathrm{r}=-\frac{\mathrm{dCOD}}{\mathrm{d} t}=\mathrm{k}[\mathrm{HO}]^{\alpha} \operatorname{COD}(\mathrm{t})=k_{\mathrm{app}} \operatorname{COD}(\mathrm{t})
$$

where, $\alpha$ is the reaction order related to the hydroxyl radicals, $k$ is the real rate constant, $k_{a p p}$ is the global apparent rate constant for COD removal.

The integration of the previous equation leads to the Eq. (12):

$$
\operatorname{COD}(\mathrm{t})=\operatorname{COD}(0) \operatorname{expk}_{\mathrm{app}} \mathrm{t}
$$

where $k_{\text {app }}$ could be calculated from the slope value of the plot of $\ln [\operatorname{COD}(0) / C O D(t)]$ versus $t$ (Figure 6$)$. The straight lines obtained in these plots were in agreement with a pseudo first-order COD removal.

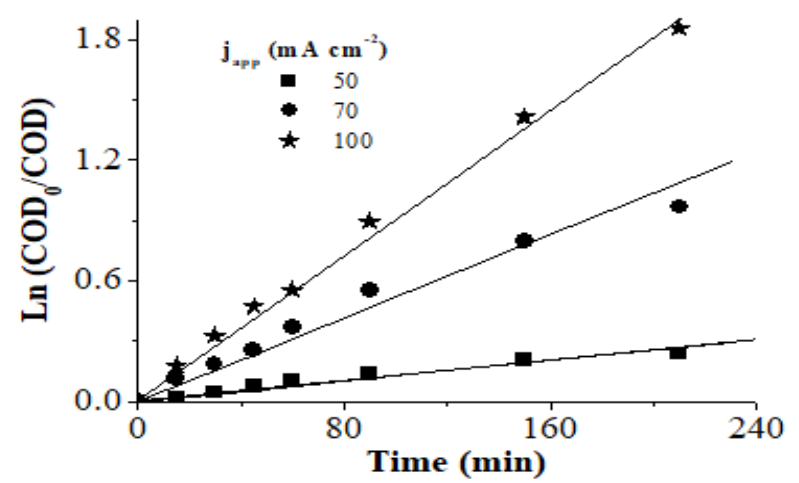

Figure 6. The linear regression for the COD removal with time during electrolysis of the IMD $\left(\mathrm{COD}_{0} 953 \mathrm{mg} \mathrm{L}^{-1}\right)$ on the $\mathrm{Ta}\left(\mathrm{PbO}_{2}\right)$ anode for different current densities. Electrolyte: $\mathrm{Na}_{2} \mathrm{SO}_{4} 2 \mathrm{~g} \mathrm{~L}^{-1}$; $\mathrm{pH}=3.0$ and $\mathrm{T}=25^{\circ} \mathrm{C}$ 
In addition, the surveillance of IMD concentration during the treatment by anodic oxidation process was followed by SWV at BDD electrode. The comparison between the COD removal and the IMD concentration during the electrolysis time is introduced in Figure 7. The results show that the molecules of IMD disappear faster than the overall organic material expressed in terms of COD. Indeed, the IMD molecules disappear completely after 200 minutes, but at the same time only $75 \%$ of the COD was removed, this explains by the formation of degradation products during the electro-oxidation of the IMD which are required more time to finish disappearing. A general reaction sequence for the electrochemical degradation of IMD is proposed in $\begin{array}{llll}\text { the } & \text { Figure } & 8 & \text { (Yujing }\end{array}$ et al., 2013).

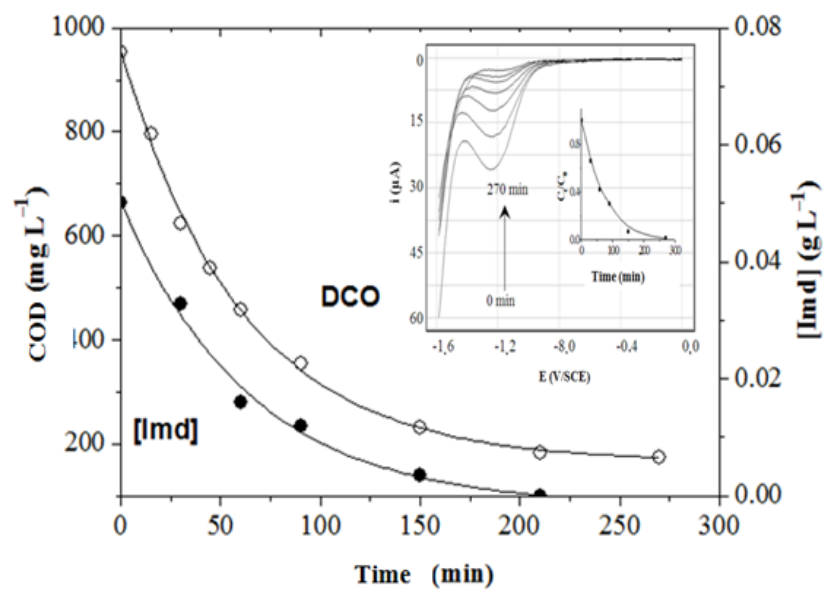

Figure 7. Evolution of COD removal and IMD concentration (followed by SWV) during electrolysis of IMD $\left(\mathrm{COD}_{0}\right.$ $\left.953 \mathrm{mg} \mathrm{L}^{-1}\right)$ on the $\mathrm{Ta}\left(\mathrm{PbO}_{2}\right)$ anode. $f=100 \mathrm{~s}^{-1}, \Delta \mathrm{E}_{i}=2 \mathrm{mV}$, $\Delta \mathrm{E}_{a}=50 \mathrm{mV}, \mathrm{pH}=3$ and $\mathrm{T}=25^{\circ} \mathrm{C}$

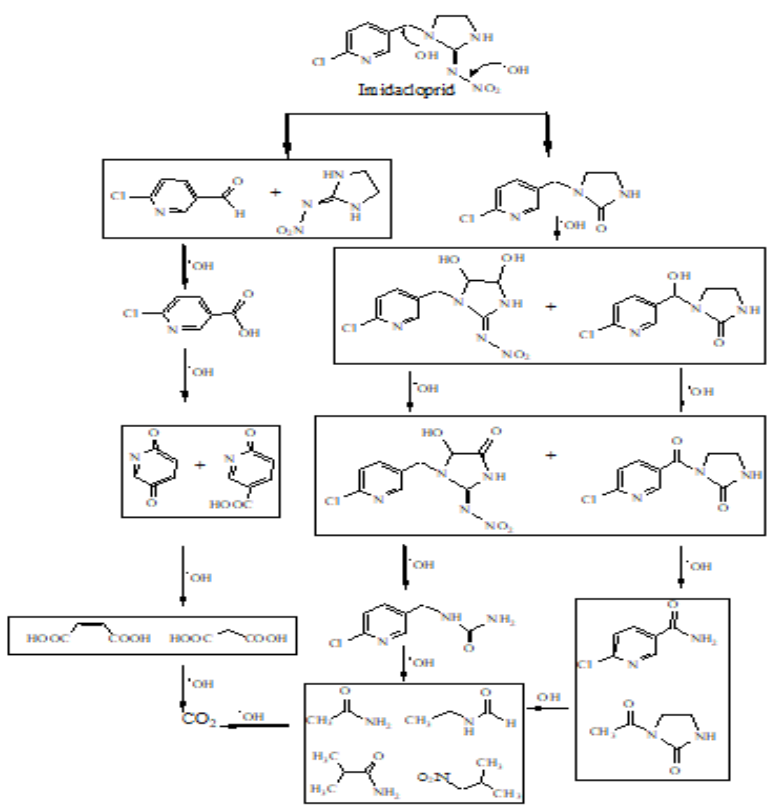

Figure 8. The proposed reaction sequence for the degradation of the IMD by ES-EF system (Yujing et al., 2013)

\subsection{Influence of $\mathrm{pH}$}

Solution $\mathrm{pH}$ is an important factor for wastewater treatment. Various works have reported on the effects of solution $\mathrm{pH}$ in anodic oxidation of organic compounds on $\mathrm{PbO}_{2}$ anode, but the results are contradictory. For example, Kirk et al. (1985) found that the current efficiency for the oxidation of aniline at a $\mathrm{PbO}_{2}$ anode increased from $3 \%$ to $13 \%$ when $\mathrm{pH}$ improved from 2 to 11 (Kirk et al., 1985). In contrast, in a previous study found that the oxidation kinetics of 4-chloroguaiacol removal using $\mathrm{PbO}_{2}$ anode was faster at $\mathrm{pH} 2$ than at $\mathrm{pH} 6$ (Samet et al., 2006). On the other hand, Panizza et al. (2008) demonstrated that the effect of $\mathrm{pH}$ was not significant for the oxidation of methyl red at $\mathrm{PbO}_{2}$ and $\mathrm{BDD}$ anodes (Panizza and Cerisola, 2008). The same result was observed by Chen and Chen (2006) when they studied the oxidation of orange II at a BDD anode (Chen and Chen, 2006). These discrepancies can be explained by the differences in the chemical properties of the organic compounds tested and the characteristic of the electrode materials (Cui et al., 2017). To study the influence of $\mathrm{pH}$ in the oxidation of IMD, electrolysis was carried out in the $\mathrm{pH}$ range of 3-10 (Figure 9).

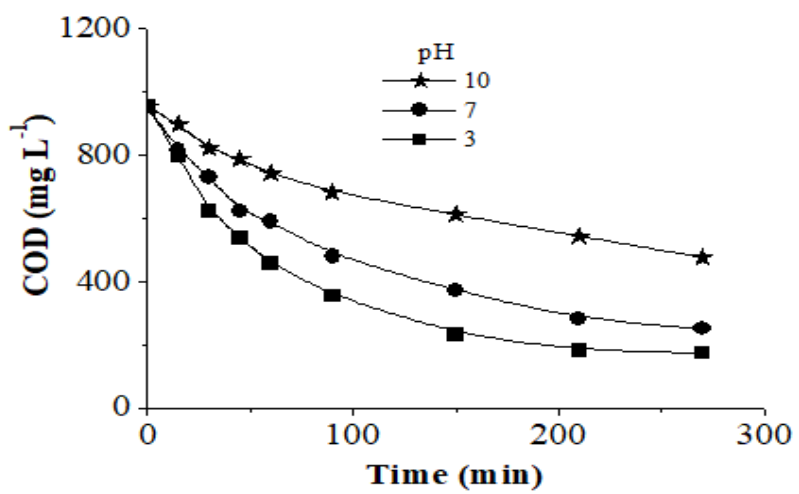

Figure 9. The influence of $\mathrm{pH}$ on the trends of $\mathrm{COD}$ during electrolysis of the IMD $\left(\mathrm{COD}_{0} 953 \mathrm{mg} \mathrm{L}^{-1}\right)$ on the $\mathrm{Ta}\left(\mathrm{PbO}_{2}\right)$ anode. Electrolyte: $\mathrm{Na}_{2} \mathrm{SO}_{4} 2 \mathrm{~g} \mathrm{~L}^{-1} ; \mathrm{j}_{\mathrm{app}}=100 \mathrm{~mA} \mathrm{~cm}^{-2}$ and $\mathrm{T}=25^{\circ} \mathrm{C}$

As can be seen from this figure, the degradation of IMD in acid medium is more efficient than in alkaline and neutral medium. This effect may be due to the extensive oxidation and/or chemical modification of the electrode surface, which suggests a change in the surface properties. This result is in agreement with previous literature reports for degradation of some pesticides (El Mouden et al., 2012). In pH = 10, we remark that the solutions become a little bit turbid after oxidation. This indicates the formation of polymeric intermediate products by the hydroxyl group that makes the degradation much more difficult (Massa et al., 2017; Rabaaoui et al., 2013). Therefore, a pH 3 was chosen as the optimal value.

\subsection{Thermodynamics studies of IMD}

In order to study the effect of reaction temperature on the removal of IMD, data were collected at four different temperatures $\left(25,35,45\right.$ and $\left.65^{\circ} \mathrm{C}\right)$ at $\mathrm{pH} \mathrm{3}$, $j_{\text {app }}=100 \mathrm{~mA} \mathrm{~cm}^{-1}$, and $\mathrm{COD}_{0}=953 \mathrm{mg} \mathrm{L}^{-1}$. The Figure 10 show that the COD removal was increased when the temperature increase from 25 to $65{ }^{\circ} \mathrm{C}$. The result is probably due to the increase in the indirect oxidation 
reaction of organics with $\mathrm{S}_{2} \mathrm{O}_{8}{ }^{-2}$ from the analyte $\left(\mathrm{Na}_{2} \mathrm{SO}_{4}\right)$ oxidation. This result is in agreement with those obtained by other authors (Serrano et al., 2002).

$$
2 \mathrm{SO}_{4}^{2-} \rightarrow \mathrm{S}_{2} \mathrm{O}_{8}^{2-}+2 \mathrm{e}^{-}
$$

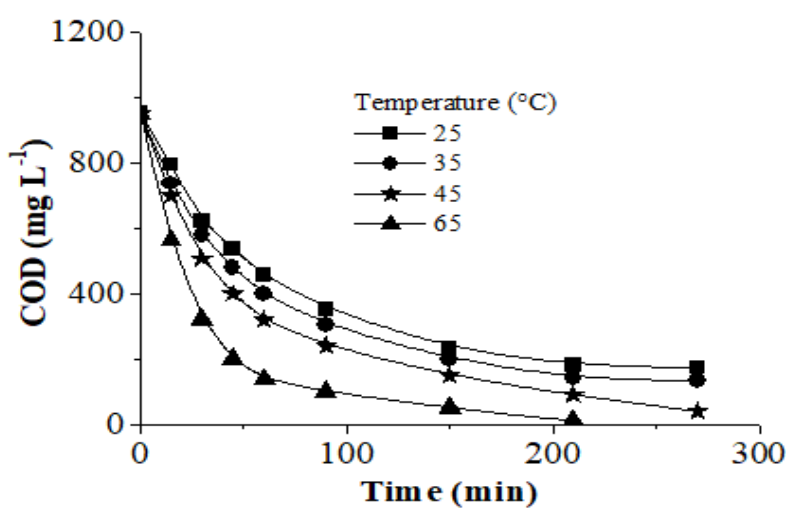

Figure 10. Influence of the temperature on the trends of COD during electrolysis of the IMD $\left(\mathrm{COD}_{0} 953 \mathrm{mg} \mathrm{L}^{-1}\right)$ on the $\mathrm{Ta}\left(\mathrm{PbO}_{2}\right)$ anode. Electrolyte: $\mathrm{Na}_{2} \mathrm{SO}_{4} 2 \mathrm{~g} \mathrm{~L}^{-1} ; \mathrm{j}_{\mathrm{app}}=100 \mathrm{~mA} \mathrm{~cm}{ }^{-2}$ and

$$
\mathrm{pH}=3.0
$$

Rate constants for chemical reactions are known to depend strongly on the reaction temperature. One well known empirical relationship expressing this dependence is the Arrhenius equation (14).

$$
\mathrm{k}_{\mathrm{app}}=\mathrm{A} \exp \left(-\frac{\mathrm{E}_{\mathrm{app}}}{\mathrm{RT}}\right)
$$

The activation free energy $\left(\Delta \mathrm{G}^{*}\right)$, the activation enthalpy $\left(\Delta \mathrm{H}^{*}\right)$ and the activation entropy $\left(\Delta \mathrm{S}^{*}\right)$ for the anodic oxidation process can be determined from the following equations:

$$
\begin{aligned}
& \Delta \mathrm{H}^{*}=\mathrm{E}_{\mathrm{a}}-\mathrm{RT} \\
& \Delta \mathrm{S}^{*}=\mathrm{R}\left(\ln \mathrm{A}-\ln \frac{\mathrm{k}_{\mathrm{B}} \mathrm{T}}{\mathrm{h}}-1\right) \\
& \Delta \mathrm{G}^{*}=\Delta \mathrm{H}^{*}-T \Delta \mathrm{S}^{*}
\end{aligned}
$$

where $k_{a p p}$ is the global apparent rate constant, $\mathrm{A}$ is the preexponential factor $\left(\mathrm{s}^{-1}\right), E_{\text {app }}$ is the activation energy $\left(\mathrm{J} \mathrm{mol}^{-1}\right), \mathrm{k}_{\mathrm{B}}$ is the Boltzmann's constant, $\mathrm{h}$ is the Planck's constant, $\mathrm{R}$ is the ideal gas constant and $T$ is the reaction absolute temperature.

Table 1. Thermodynamic parameters for anodic oxidation of IMD

\begin{tabular}{ccccc}
\hline$T\left({ }^{\circ} \mathrm{C}\right)$ & $E_{\mathrm{a}}\left(\mathrm{kJ} \mathrm{mol}^{-1}\right)$ & $\Delta H^{*}\left(\mathrm{~kJ} \mathrm{~mol}^{-1}\right)$ & $\Delta S^{*}\left(\mathrm{~J} \mathrm{~mol}^{-1} \mathrm{k}^{-1}\right)$ & $\Delta G^{*}\left(\mathrm{~kJ} \mathrm{~mol}^{-1}\right)$ \\
\hline $\mathbf{2 5}$ & 19.70 & 17.222 & $-8,05$ & 19.620 \\
\hline $\mathbf{3 5}$ & & 17.139 & -7.37 & 19.408 \\
\hline $\mathbf{4 5}$ & & 17.057 & -6.169 & 19.018 \\
\hline $\mathbf{6 5}$ & & 16.889 & -4.087 & 18.270 \\
\hline
\end{tabular}

The results of the thermodynamic calculations are shown in Table 1 . The apparent activation energy is $19.70 \mathrm{~kJ} \mathrm{~mol}^{-1}$. This value is less than $40 \mathrm{~kJ} \mathrm{~mol}^{-1}$ indicating that the system was under mass transport control (BelhadjTahar and Savall, 1998). Moreover, the positive value for the Gibbs free energy at all temperatures indicate that the oxidation reaction of IMD is non-spontaneous in nature and that the degree of the nonspontaneity of the reaction decreased by increasing temperature. The positive $\Delta \mathrm{H}^{*}$ refer to endothermic reaction and the negative value of $\Delta S^{*}$ suggests that the intermediate formed during the oxidation of IMD is more ordered than the reactants.

\section{Conclusion}

This work is a first attempt to investigate the degradation of IMD in electrochemical treatment with $\mathrm{Ta}\left(\mathrm{PbO}_{2}\right)$ anode. Electrochemical oxidation is a method that has been utilized to date for the treatment of several types of wastes. This paper provides new results on the electrochemical degradation of IMD and led to the following points:

- $\mathrm{Ta}\left(\mathrm{PbO}_{2}\right)$ anode displayed noticeable oxidation abilities for treating wastewaters containing this pesticide, due to the production of a large amount of hydroxyl radicals on the electrode surface during electrolysis.

- the removal rate of COD increases with applied current density until $100 \mathrm{~mA} \mathrm{~cm}^{-2}$ due to the increase of the mass transport caused by oxygen evolution reaction,
- the evolution of COD with electrolysis time followed a pseudo first-order kinetics.

- the increased current density resulted in a decrease in current efficiency. Moreover, an increase in IMD concentration enhanced the degradation rate due to the increase in the organic matter diffusion flux as well as a decrease of the oxygen's formation rate.

- the effect of temperature showed that for $25^{\circ} \mathrm{C}$ and 65 ${ }^{\circ} \mathrm{C}$ the achieved reduction was $82 \%$ and $99 \%$. The apparent global activation energy was found as $19.70 \mathrm{~kJ} \mathrm{~mol}^{-1}$.

- the increases of $\mathrm{pH}$ from acidic to alkaline medium decreased slightly the electrochemical removal of IMD.

\section{Acknowledgements}

This work was financially supported by the Tunisian Higher Education and Scientific Research Ministry.

\section{References}

Belhadj Ammar H., Ben Brahim M., Abdelhédi R. and Samet Y. (2016), Green electrochemical process for metronidazole degradation at BDD anode in aqueous solutions via direct and indirect oxidation, Separation and Purification Technology, 157, 9-16.

Belhadj-Tahar N. and Savall A. (1998), Mechanistic aspects of phenol electrochemical degradation by oxidation on a $\mathrm{Ta} / \mathrm{PbO}_{2}$ anode, Journal of The Electrochemical Society, 145, 3427-3434. 
Ben Brahim M., Belhadj Ammar H., Abdelhédi R. and Samet Y. (2016), Electrochemical removal of the insecticide imidacloprid from water on a boron-doped diamond and $\mathrm{Ta} / \mathrm{PbO}_{2}$ anodes using anodic oxidation process, Korean Journal of Chemical Engineering, 33, 2602-2609.

Bokare A.D. and Choi W. (2014), Review of iron-free Fenton-like systems for activating $\mathrm{H}_{2} \mathrm{O}_{2}$ in advanced oxidation processes, Journal of Hazardous Materials, 275, 121-135

Chen G.H. (2004), Electrochemical technologies in wastewater treatment. Separation and Purification Technology, 38, $11-41$.

Chen X. and Chen G. (2006), Anodic oxidation of Orange II on Ti/BDD electrode: Variable effects, Separation and Purification Technology, 48, 45-49.

Comninellis C. and Pulgarin C. (1991), Anodic oxidation of phenol for wastewater treatment, Journal of Applied Electrochemistry, 21, 703-708.

Cui T., Zhang Y., Han W., Li J. and Sun X. (2017), Advanced treatment of triazole fungicides discharged water in pilot scale by integrated system: Enhanced electrochemical oxidation, upflow biological aerated filter and electrodialysis, Chemical Engineering Journal, 315, 335-344.

Ecobichon D.J. (2012), Pesticide use in developing countries, Toxicology, 160, 27-33.

El Mouden O.I.D., Errami M., Salghi R., Zarrouk A., Assouag M., Zarrok H., Al-Deyab S.S. and Hammouti B. (2012), Electrochemical degradation of difenoconazole on BDD electrodes, Journal of Chemical and Pharmaceutical Research, 4, 3437-3445.

Johnson A.C., Besien T.J., Bhardwaj C.L., Dixon A., Gooddy D.C., Haria A.H. and White C. (2001), Penetration of herbicide to groundwater in an unconfined chalk aquifer following normal soil applications, Journal of Contaminant Hydrology, 53, 101117.

José M.A., Romeu C.R., Nerilso B. and Sonia R.B. (2013), Electrochemical degradation of the disperse orange 29 dye on a $\beta-\mathrm{PbO}_{2}$ anode assessed by the response surface methodology, Journal of Environmental Chemical Engineering, 1, 954-961.

Kadian N., Gupta A., Satya S., Mehta R.K. and Malik A. (2008), Biodegradation of herbicide (atrazine) in contaminated soil using various bioprocessed materials, Bioresource Technology, 99, 4642-4647.

Kirk D.W., Sharifian H. and Foulkes F.R. (1985), Anodic oxidation of aniline for waste water treatment. Journal of Applied Electrochemistry, 15, 285-292

Kolthof I.M., Sandell E.B., Meehan E.J. and Buckstein S. (1969), Quantitative Chemical Analysis, 4th Eds., Macmillan, New York, pp. 1862-1867.

Massa A., Hernández S., Lamberti A., Galletti C. and Russo N. (2017), Electro-oxidation of phenol over electrodeposited $\mathrm{MnO}_{x}$ nanostructures and the role of a $\mathrm{TiO}_{2}$ nanotubes interlayer. Applied Catalysis B: Environmental, 203, 270-281.

Mullins J.W. (1993), Imidacloprid: a new nitroguanidine insecticide, ACS Symposium Series, 524, 183-198.

Olfa D.G., Samet Y. and Abdelhedi R. (2013), Electrocatalytic performance of $\mathrm{PbO}_{2}$ films in the degradation of dimethoate insecticide, Water SA, 39, 31-38.
Panizza M. and Cerisola G. (2005), Application of diamond electrodes to electrochemical processes, Electrochimica Acta, 51, 191-199.

Panizza M. and Cerisola G. (2008), Electrochemical degradation of Methyl Red using $\mathrm{BDD}$ and $\mathrm{PbO}_{2}$ anodes, Industrial \& Engineering Chemistry Research, 47, 6816-6820.

Paranthaman R., Sudha A. and Kumaravel S. (2012), Determination of pesticide residues in banana by using high performance liquid chromatography and gas chromatography-mass spectrometry, American Journal of Biochemistry and Biotechnology, 8, 1-6.

Rabaaoui N., Moussaoui Y., Allagui M.S., Bedoui A. and Elaloui E. (2013), Anodic oxidation of nitrobenzene on BDD electrode: variable effects and mechanisms of degradation, Separation and Purification Technology, 107, 318-323.

Rkik M., Ben Brahim M. and Samet Y. (2017), Electrochemical determination of levofloxacin antibiotic in biological samples using boron doped diamond electrode, Journal of Electroanalytical Chemistry, 794, 175-181.

Samet Y., Chaabane Elaoud S., Ammar S. and Abdelhedi R. (2006), Electrochemical degradation of 4-chloroguaiacol for wastewater treatment using $\mathrm{PbO}_{2}$ anodes, Journal of Hazardous Materials, 138, 614-619.

Serrano K., Michaud P.A., Comninellis C. and Savall A. (2002), Electrochemical preparation of peroxodisulfuric acid using boron doped diamond thin film electrodes, Electrochimica Acta, 48, 431-436.

Sires I., Brillas E., Cerisola G. and Panizza M. (2008), Electrochemical oxidation as a final treatment of synthetic tannery wastewater, Journal of Electroanalytical Chemistry, 613, 151-159.

Tomizawa M. and Casida J. (2005), Neonicotinoid insecticide toxicology: mechanisms for selective action, Annual Review of Pharmacology and Toxicology, 45, 247-268.

Torres R.A., Torres W., Peringer P. and Pulgarin C. (2003), Electrochemical degradation of $p$-substituted phenols of industrial interest on $\mathrm{Pt}$ electrodes. Attempt of a structure-reactivity relationship assessment, Chemosphere, 50, 97-104.

USEPA: United States Environmental Protection Agency. National Primary Drinking Water Regulations. EPA 816-F-09-004 May 2009.

Wen L., Ming S. and Minzan L. (2013), A Survey of Determination for organophosphorus pesticide residue in agricultural products, Advance Journal of Food Science and Technology, 5, 381-386.

Xiaoyue D., Fang M., Zhongxin Y., Limin C. and Xintong J. (2013), Electrochemical degradation of phenol in aqueous solution using $\mathrm{PbO}_{2}$ anode, Journal of the Taiwan Institute of Chemical Engineers, 44, 95-102.

Xu H., Yuan Q., Shao D., Yang H., Liang J., Feng J. and Yan W. (2015), Fabrication and characterization of $\mathrm{PbO}_{2}$ electrode modified with $\left[\mathrm{Fe}(\mathrm{CN})_{6}\right]^{3-}$ and its application on electrochemical degradation of alkali lignin, Journal of Hazardous Materials, 286, 509-516

Yujing W., Hongying Z., Shouning C., Yabo W., Guohua Z. and Dongming L. (2013), Electrosorption enhanced electro-Fenton process for efficient mineralization of imidacloprid based on mixed-valence iron oxide composite cathode at neutral $\mathrm{pH}$, Chemical Engineering Journal, 223, 524-535. 